\author{
Joanna Jędruszkiewicz \\ Pedagogical University of Kraków \\ Institute of Geography \\ Department of Sustainability and Development of the Geographical Environment \\ joajed@up.krakow.pl
}

Piotr Moniewski

The Regional Inspectorate of Environmental Protection in Łódź WIOŚ laboratory in Łódź, piotr.moniewski@geo.uni.lodz.pl

\title{
PAST INDUSTRIAL TRACES OF THE JASIEŃRIVER IN THE TOURISM SPACE OF ŁÓDŹ
}

\begin{abstract}
In the paper the characteristics of one of the most valuable rivers in Łódź, the Jasień, are described. The Jasień is a unique example of a river once working for industry but now existing as untapped tourism potential despite its negative image and even being partly forgotten. The description of the most valuable historical hydro-technical work along the river's course is given with some useful historical information. In the summary, a suggestion of how the river bank might become a trigger for studying Łódź's history, as its industrial development was so strongly related to the river network.
\end{abstract}

Keywords: anthropopressure, water energy, Łódź, urban tourism space, river.

\section{INTRODUCTION}

Crossword. Five down: what river is Łódź located on? Easy as it seems... it is obvious that it's ... Wait ... How many letters would an average citizen of Łódź write... five? What if there are six boxes? Let us think, which river would deserve to be called the most valuable? And what does the most valuable mean? Is it the same as the first? From a historical point of view the settlement process was almost always determined by the hydrographic network. Thus probably the Sokolówka should be the first. Its waters might have protected access to a small watchtower which was erected near the river crossing or to the settlement of Radogoszcz. This name was mentioned at a meeting of Polish dukes in 1242, but its location remains unknown.

The basic framework of the Polish settlement network was created in the early Middle Ages. During that time, most villages were located by rivers which demarcated the direction of their expansion. The location of settlements was determined by varied factors defensive, strategic, sanitary, trade, agricultural, transportation and other. Many were transformed into towns, connected by land or water routes and the water was primarily used for drinking, municipal, agricultural, transportation and energy purposes. One of the oldest Polish cities (Kalisz) was built by the Prosna. On the banks of Vistula, port and trading cities such as Sandomierz, Kazimierz, Włocławek and Torun were located and along its lower section the Amber Trail has been laid out.

As a result of economic change and contamination of surface water, towns turned away from rivers. Nonetheless, the rivers are usually still present in the urban space, even if their genuine functions were forgotten a long time ago. No one can even imagine Wawel without the Vistula, or the Gdansk Crane without the Motława, or Malbork Castle without the Nogat. What would have been the fish market in Bydgoszcz without the Brda, or Ostrów Tumski in Wroclaw or Poznań without the Odra?

Today, inhabitants willingly chose river banks as places for walking, leisure and relaxation or even active recreation. Rivers have become a component in modern tourism space (LISZEWSKI 1995, p. 88) numerous examples of promenades, parks and riverside boulevards, not only in Warsaw (the Vistula), Opole and Gorzów Wielkopolska (the Odra), Piła (the 
Gwda), Elblacg (the Elblag), Serock (the Narew), but also minor rivers like the Supraśl (in Supraśl), the Młynówka (in Cieszyn), the Postomia (in Sulęcin), the Zgtowiaczka (in Włocławek), the Eupia (in Skierniewice) and in many other places. In recent years, a successful development of the quays can be seen in Tczew (the Vistula), Szczecin-Dąbie (the Płonia), Gryfin (the East Odra), Łowicz (the Bzura) and in Chełm (the Uherka). Similar projects have a fair chance of launching in Gdynia (the Kacza) and Nowogród (the Narew). Stimulation of positive changes in the structure of riverbanks and floodplains improves rivers' attractiveness among inhabitants (MAURER 2013, p. 152). Increasing the attractiveness of river areas is a part of urban projects under the REURIS program - Revitalisation of Urban River Spaces. This international program, which is coordinated by the Central Mining Institute in Katowice, supports the renaturalisation of the Slepiotka in Katowice and the revitalization of the old canal in Bydgoszcz (KOZŁOWSKA 2012, pp. 8-10).

The river valley is often associated with hydrotechnical constructions: bridges, dams, mills, power plants which themselves might become tourism attractions. As a result of weak connections to urban space, a great number of these have not stood the test of time. Even such gems as the Elblacg Canal or the hydropower station on the Radunia, were located outside towns. Nowadays, historical hydro-technical constructions in cities are used only occasionally. Castle Mill in Stupsk located on the Stupia is an example of one of the oldest buildings equipped with a water turbine which is still in operation. Examples of sites whose function has shifted are the Great Mill in Gdańsk (shopping centre), Castle Mill in Torun (hotel and restaurant), 'Strauchmühle' in Elblag and the mill in Pelplin (hotels).

Water, present in cities in many forms, has usually become a basis for recreation - ponds and fountains are located in most parks. Although, during summer days they attract inhabitants, generally they have recreational and landscaping functions. In addition ponds which are present inside the city can become an environment for many organisms. From the hydrological point of view, the ponds raise and balance the water table in a river valley, while at the same time mitigate floods and increase the occurrence of low flows. Furthermore, flow-through ponds improve water quality. Nevertheless, the reduction of contamination in water takes place only during the growing season and for the rest of a year the aquatic plants die and release contaminants back into the water. That kind of reservoir results in a water-flow decrease and heavy metal deposition in sediments. The water temperature increases in summer reducing the amount of oxygen which can be dissolved. Additionally, winter ice cover reduces, or even blocks the oxygen exchange with the atmosphere which is required to decompose the chemical compounds. In adverse circumstances it might result in the development of anaerobic processes, hydrogen sulphide formation or oxygen starvation in fish. The solution is to create open and shady sections and diversify the water flow character (waterfalls, rapids, hollows), which improve water quality and control water temperature on the basis of free groundwater discharge. Another solution might be the construction of a 'parallel reservoir' in the proximity of the watercourse.

\section{2. ŁÓDŹ - A CITY (NOT) BY A RIVER}

18 watercourses flow through the area of Łódź (Fig. 1) with a cumulative length of $125.6 \mathrm{~km}$ (BIEŻANOWSKI 2003, p. 20, Ilustrowana Encyklopedia ... 2009, p. 7). In the city landscape, any river plays a dominant role. Mainly they collect rainwater from streets and roofs but due to poor water quality in the $20^{\text {th }} \mathrm{c}$. a great number of rivers were shifted under the ground. Even though the positive changes in the drainage system and wastewater treatment did not embrace the whole city of Łódź (MAURER 2013, p. 154). Today, it might be possible that those watercourses could be brought back onto the surface. In Łódź as in other cities, riverside areas might become ecological corridors and paths for alternative forms of individual transport (cycling, walking). There are only a few recreational paths alongside water bodies in Łódź. The best known are Stefański Pond (the Ner), the forest in Arturówek (the upper Bzura), pond cascade in Zdrowie Park (a Łódka tributary). Generally, green areas are divided or bounded by major traffic routes (i.e. along the Sokotówka and Olechówka). The main issue of the SWITCH (Sustainable Water Management Improves Tomorrow's Cities' Health) project is to restore the ecological and landscape character of the Sokotówka. Examples of successful investments are flood protection reservoirs (the upper course), a lateral reservoir 'Teresa', the flowthrough reservoir 'Żabieniec', the dry reservoir 'Wasiak Pond' and the biofilter in Julianowski Park. Although until now no section of the Sokotówka has been reconstructed.

The Łódka, located in the northern part of the city, played a prominent role in the history of Łódź. The agricultural settlement ' $Ł o d z i a^{\prime}$ was developed by this river. The river had many names in the past: 'Ostroga', 'Struga Starowiejska' or 'Stara Struga'. Its course linked a manor and the 'city', and demarcated Drewnowska and Ogrodowa Sts. So, has the Łódka played a significant role for industrial Łódź? The answer is: yes, and no. The river was neither extensive nor abundant in 


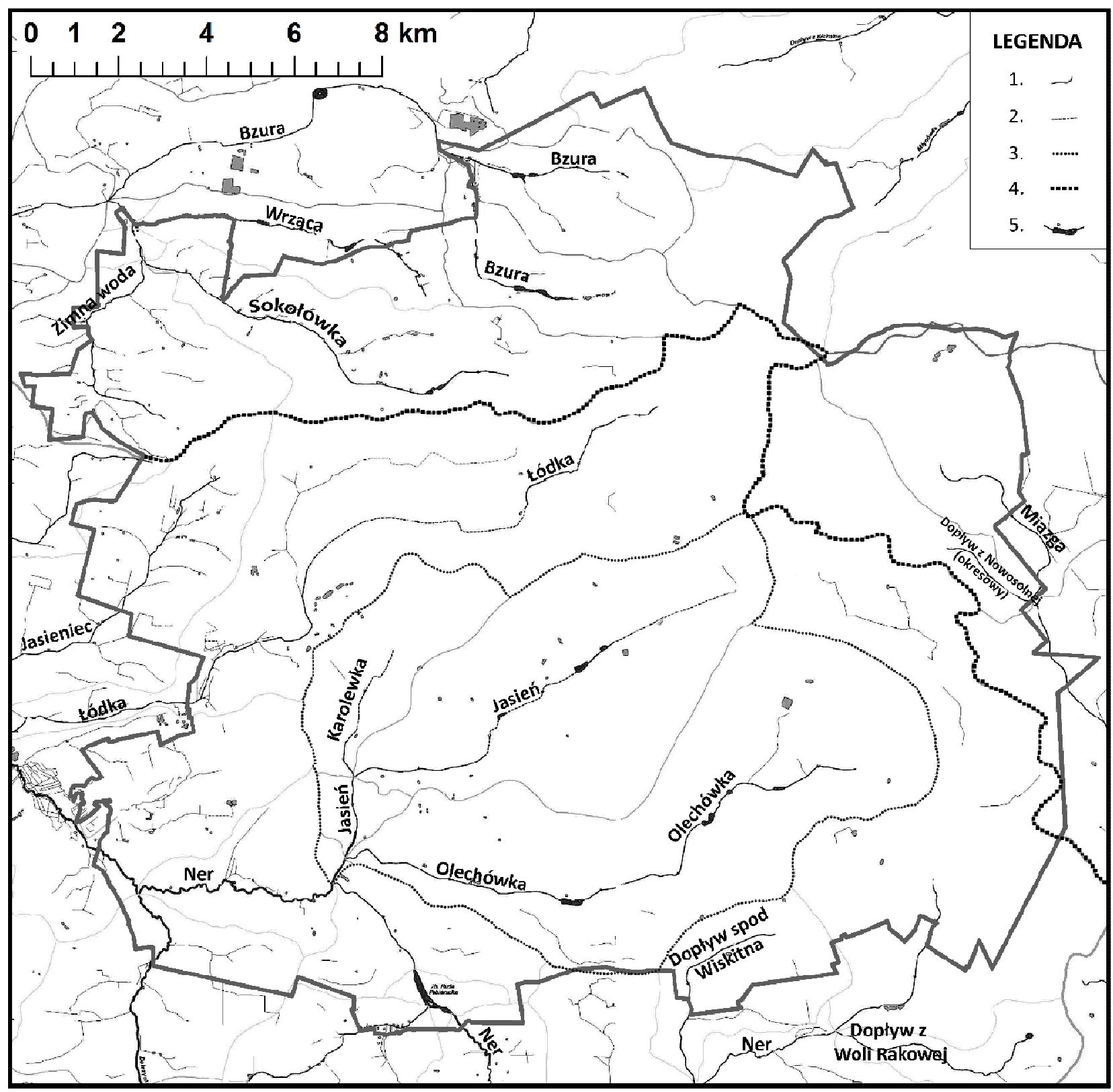

Fig. 1. The Jasień catchment area on the basis of hydrographic network of Łódź:

1 - river, 2 - section of underground watercourse, 3 - watershed of the Jasien catchment area, 4 - first order watershed (Vistula-Odra), 5 - water reservoir Source: authors on the basis of Rastrowa Mapa ... (2010)

water and only the Grobelny Mill was operated during that time. The Łódka had little energy potential, however it provided an important border between the Old and New Towns. In the place where a mill was destroyed by a flood in 1817, a fulling mill was built and rented by the Dutchman J. Peters (FLATT 1853, p. 62). In 1823 a broadcloth dye-house was erected by K.B. Saenger and reconstructed again later as a brewery. For many decades, the Łódka was contaminated by sewage released by for instance the wool spinning mill of A. Prossak (1859), yarn, wool and cotton dye-house of R. Bidermann (1862), steam brewery of K. G. Anstadt (1866) and the cotton empire of I. Poznański (1871). During the interwar period, the river channel was straight and flowed openly through the district inhabited by Jewish poverty (today known as the Old Town Park). In the 1930s the river was engineered and after the Second World War it was hidden under the ground in a culvert. Today, the river is completely invisible and attempts to expose it on the surface did not succeed. In July 2015 the Waterworks and Sewage System Company in Łódź installed the 
'Łódka Eye' in the Old Town Park, which enabled the river to be seen.

The original border of the industrial city was partly determined by the Eódka, not by the loom, nor the fulling mill but the mechanization of the production which could be only provided by water energy. The water energy of rivers was commonly used to drive mills (Fig. 2). At that time, 135 mills were operating in the surroundings of Łódź, but most of them were located at the outskirts (JOKIEL \& MAKSYMIUK 2002, p. 9). In 1824 the textile settlement ' $Ł o ́ d k a '$ was demarcated on the basis of hydro-technical constructions located by the most powerful river - the Jasien (BARANOWSKI et al. 1980, p. 161).

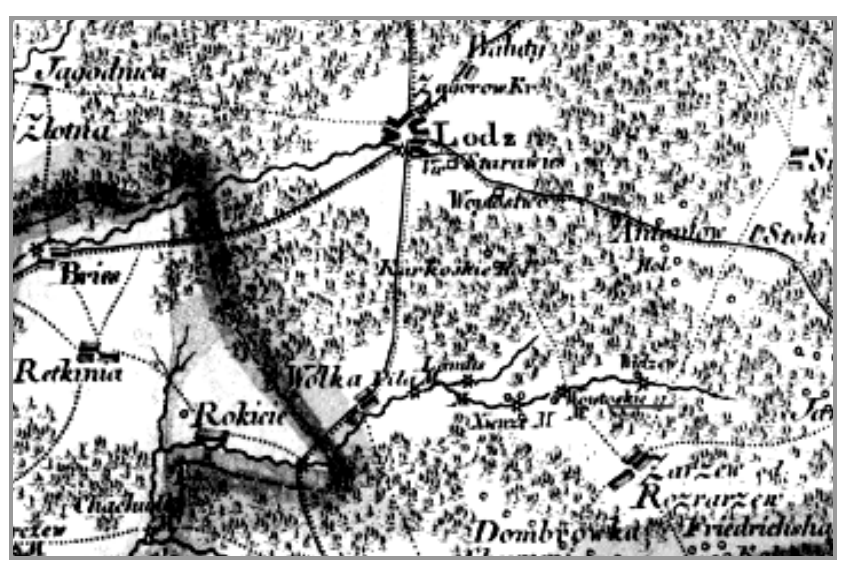

Fig. 2. Part of the special Karte von Südpreussen, sheet C III, D. Gilly, 1802-3 from the Łódź University Library collection - K 159, which presents mill locations by the Jasien: Araszt, Wójtowski, Księży, Lamus, Kulam (Piła), Rokicki i Chachuła; and by the Łódka: Grobelny and Brus

\section{THE POWER OF THE JASIEŃ}

There are few hydro-technical constructions in Łódź which have historical background. They are generally unknown to inhabitants and stay in the shade of factories and palaces. It is rarely remembered that the factories fortunes origins 'drank the water' from the hydrographic network. However, today's feeble streams are not reminiscent of their face from historical times.

The Jasien is one of the largest and longest $(12.7 \mathrm{~km})$, but hardly visible. Despite this its character resembles a mountain stream with a gradient of $5.6 \%$ in its middle course. Its nearly depleted source is located in Stoki, near Pomorska St (245 m a.s.l.). In a distance of $1.7 \mathrm{~km}$ from the source the stream for the first time disappears under the ground for a length of one $\mathrm{km}$. It appears again for a short distance in Widzewski Park, near a one-hectare pond, giving a landscape function and preventing floods. The stormwater overflow structure (Fig. $3-1$ and Photo 1) located in the north eastern part of the park, moves excess water to the pond. Below the pond a stream of water, which comes from Łódź Fabryczna Railway Station, joins the Jasien under the ground. The pond existed in the times of the former Widzew village and the amount of water stored in it was not enough for industrial processes. Therefore, Araszt Mill's location on the pond seems unjustified. In fact, it was placed further away, beyond Widzew's borders, approximately $300 \mathrm{~m}$ above Wójtowski Mill. Due to its close distance to the river source, it was the smallest mill along the Jasien. The Araszt Mill, named after one of its owners, was constructed at the turn of the $17^{\text {th }} \mathrm{c}$. and stopped operating in 1686. According to different inventories, many breaks took place during mill operations from the $18^{\text {th }} \mathrm{c}$. to the $1820 \mathrm{~s}$. Nowadays, there are no traces of the mill's existence because during the construction of the Anilana plant the ground surface was raised by several meters. The river hides again under the ground and appears on the surface in the park where the river bed is crossed by an embankment carrying a siding of the 'Scheibler Railway' (Fig. 3 - 2). In this section, a spring was found.

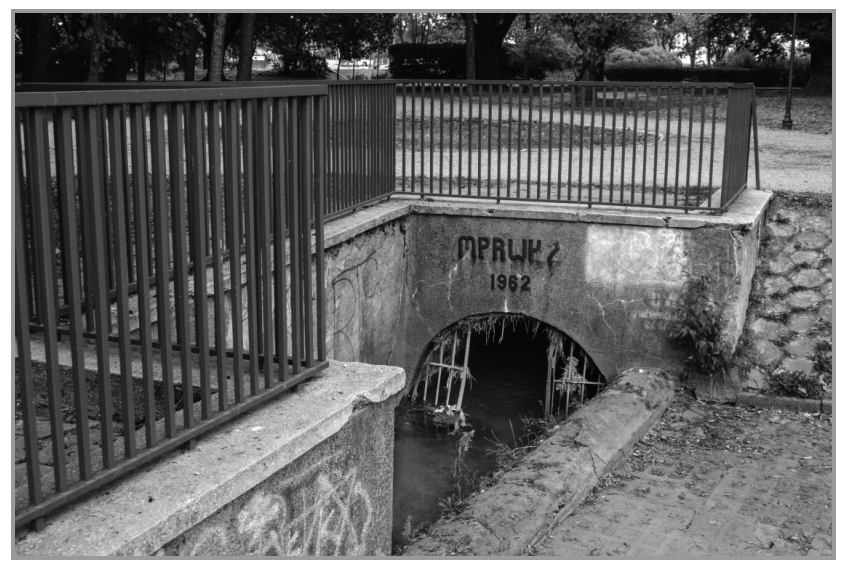

Photo 1. Stormwater overflow by the Jasień in Widzewski Park Photo: J. Jędruszkiewicz

There is a pond in the middle course of the Jasien where the Wójtowy (Wójtowski) Mill was located. The first mill was probably constructed around 1387 (date of right of construction). But the first reference could be found only in 1428 and records in 1484. Jakub Chrapowicz was the first owner of the mill. The act of legal assignment was approved by Bishop of Kujawy in 1605 and remained in the family for the next 300 years. The wooden construction from probably 1595 was rebuilt numerous times and the last rebuilding was as property of the municipality. This property was used for Łódź clothiers' settlement. In 1825 


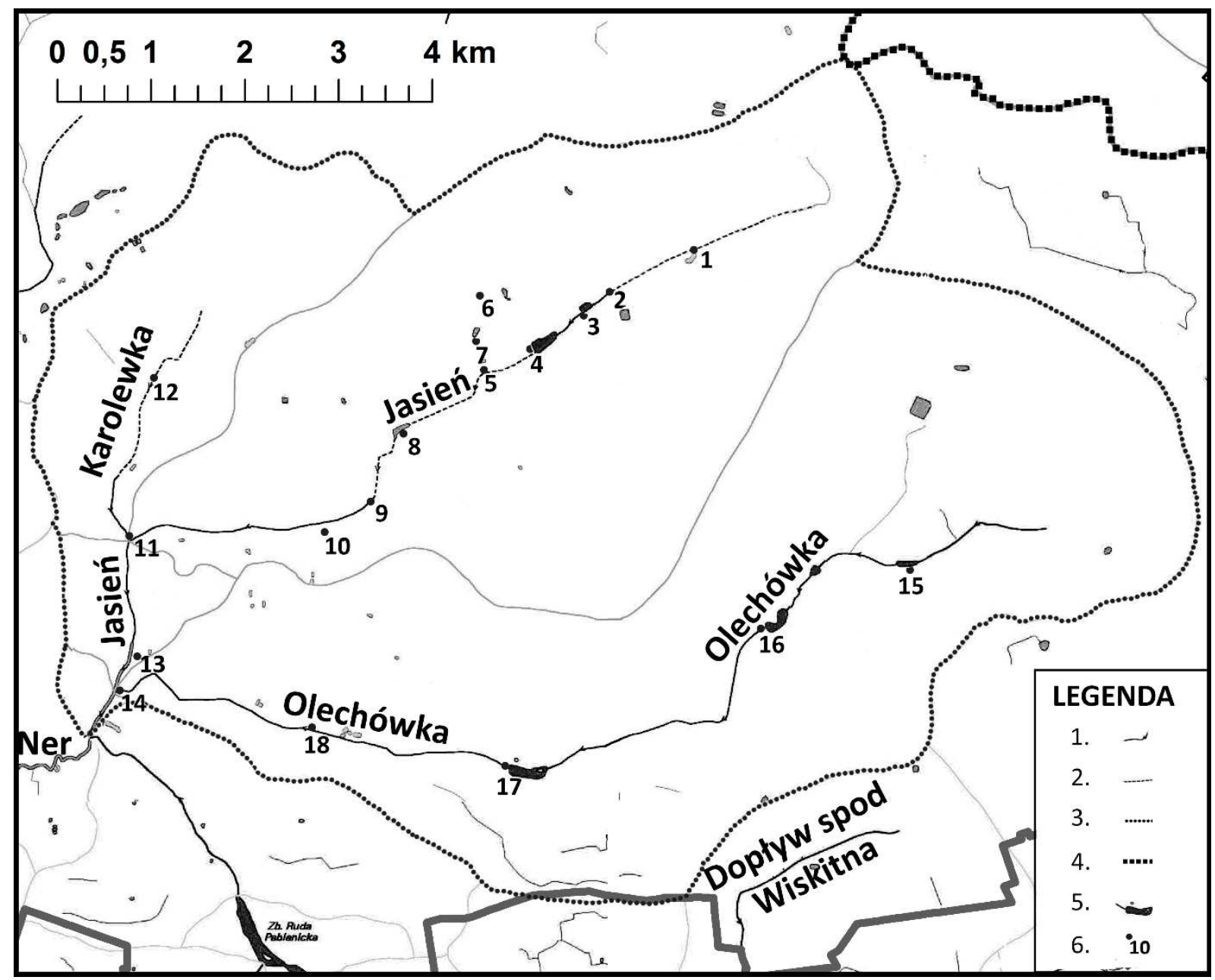

Fig. 3. Hydrographic network of the Jasien catchment: 1 - river, 2 - section of subsurface watercourse, 3 - watershed of the Jasien catchment area, 4 - First order watershed (Vistula-Odra), 5 - pond, 6 - hydro-technical constructions of the Jasien catchment (explained in the text): 1 - stormwater overflow near Widzewski Park, 2 - Araszt Mill, 3 - Wójtowski Mill, 4 - Księży Mill, 5 - Kulam Mill, 6 - spring in Źródliska Park, 7 - Lamus Mill, 8 - pond in Reymont Park, 9 - Jasień and Dąbrówka, 10 - Rokicie Mill, 11 - Karolewka river, 12 - Bączek Mill, 13 - Chachuły Mill, 14 - Olechówka river, 15 - 'Olechów Górny' pond, 16 - Wiskicki Mill, 17 - Chojeński Mill, 18 - ‘Rzemieślnicza Dolny' pond Source: Authors on the basis of Rastrowa Mapa ... (2010)

a brick, multi-storey spinning mill was built by Ch.F. Wendisch, just below the old Wojtowski Mill. The application of water power was possible due to a reservoir with a size of 1.2 ha and average depth of $1.2 \mathrm{~m}$, and the existence of two more reservoirs above (in Widzewski Park and Araszt). In 1845, fifteen years after Wendisch passed away, the mill was bought by K. Moes, then to T. Krusche, and after that in 1870 to K.W. Scheibler who set up a farm there. The building with its spinning mill was closed in 1876-87. In the 1880s the house of the manor manager was built on the brick foundation of old Wójtowski Mill (Fig. 3 - 3 and Photo 2).

In the further course of the Jasien, the water flows through the allotments which were placed on the old Scheibler manor grounds. The largest pond on the opposite site of Rydza-Śmigłego St neighboured Księży Mill from the $14^{\text {th }}-15^{\text {th }} \mathrm{c}$. In the $18^{\text {th }} \mathrm{c}$. it was the greatest two-wheeled mill $(8.3 \times 7.1 \mathrm{~m})$ with a reservoir size of 0.8 ha and area of about 51 ha. Probably the first wheel was responsible for milling grain into flour and the other one for coarse meal production. The last wooden building was burnt on the night of $10^{\text {th }}$ May 1822 . Only the construction of weirs was used for the new settlement and the pond area was extended to 5 ha by an increase in the dam height (today - Przędzalniana St). The mill was replaced by a bleaching plant which also burnt down in 1870. After Wendisch's death, the plant was bought by K.F. Moes who ran a spinning mill powered by water in a new building. In 1854 the water power was supplemented by a steam engine of $30 \mathrm{hp}$. After the fire in 1863 the spinning 
mill was bought by $\mathrm{T}$. Krusche and later in 1870 by K.W. Scheibler. That building still exists (Fig. $3-4$ and Photo 3). In 1870-3, the greatest $(207 \times 35.5 \mathrm{~m})$ spinning mill in Łódź was built nearby by Scheibler (PUŚ 1987, p. 41). During that time, the pond by the Jasien was no longer used as a hydropower source but was a part of the Herbst mansion landscape. In the 1970s, after reconstruction of Rydza-Śmigłego St, the pond size was reduced to 3.46 ha. Nowadays, its depth is $2.2 \mathrm{~m}$ and impoundment elevation comes to $4.23 \mathrm{~m}$. In winter 2013/14 the reservoir was thoroughly cleaned and was refilled with water in 2015.

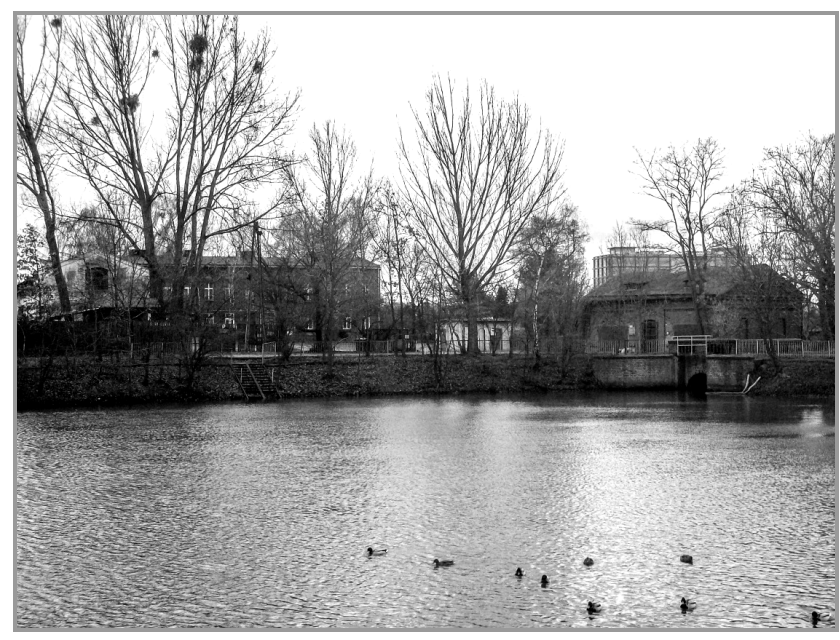

Photo 2. The pond in the park by the Jasien: old buildings of the Scheibler manor, the house of the manor manager and the weir Photo: P. Moniewski

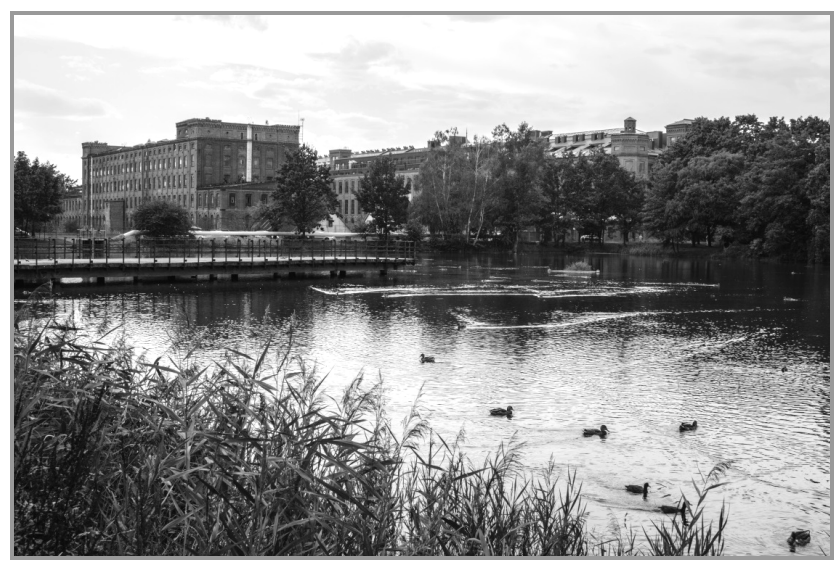

Photo 3. The pond by the Jasien, next to Przędzalniana St, the old Wendisch/Moes spinning mill and Scheibler's new spinning mill

Photo: J. Jędruszkiewicz

Behind Przędzalniana St, the course of the Jasien is hidden again in a culvert under the ground. In that section there was another mill with a pond where the course of the river ran on the surface in the past, named Kulam (Kulom, Kulan) after its tenant. In 1760 the two-wheel mill was burnt down and reconstructed as a sawmill, itself swept away by Jasien water in 1817. After that event, the dam (today - Kilińskiego St) was heigtened by $2 \mathrm{~m}$. The water from the greatest Bielnikowy Pond regulated by the culvert with a length of $750 \mathrm{~m}$ was used to power the bleaching plant and fulling mill, located on Emilii St (today - Tymienieckiego St). Nowadays, the School Sports Championships are held there (Fig. 3 - 5).

The energy potential of that river course was highly impressive and allowed mill wheels to be powered for 14-16 hours per day, even during dry periods (RYNKOWSKA 1960, p. 33). According to Staszic's report, the river fell by $17 \mathrm{~m}$ in a distance of $2.1 \mathrm{~km}$. The gradient between Splaszczenie Rogowskie and Stopień Śródmiejski (GOŹDZIK \& WIECZORKOWSKA 2002, p. 8) is about 8\%o (CYMERMAN 2012, p. 18). In 1860, the river channel was $30 \mathrm{~cm}$ in depth and $2.4 \mathrm{~m}$ wide (KOTER 1974, p. 19). Additionally, Kulam Pond received water from a tributary whose source was in Źródliska Park II.

Źródliska Park II was laid out in 1840 from oldgrowth forest with numerous springs. Unfortunately, as a result of a permanent decrease in the water table, only one spring is still active. The original spring called 'Water Market' was located higher up, near Nawrot St. In the place of other springs, only shallow depressions are still recognizable. The old eastern part of the park (Źródliska Park I) was called Kwela, taken from German Quell - meaning spring (Fig. 3 - 6). A temporary subsurface stream flows along the valley under Fabryczna St.

Further along the tributary a pond is located which could have been established in the $16^{\text {th }} \mathrm{c}$. The watercourse which took its origins in Źródliska Park powered the new mill, named Krępski (Krępa) after its owner, Krupa. According to 'Rozwoój' magazine later tenants were Marcin Lamus, Roch Krupa and Andrzej Las-kowski who obtained lands in Kąty and Widzew in exchange for the mill. Despite the slow flow of the watercourse, the gradient was quite significant at 9 or even 12\%o (KOTER 1974). In 1826 the mill was rented by Ch.F. Wendisch who constructed a wooden cotton cleaning plant. It was not until 1843, that T. Grohman constructed the first cotton spinning mill there and later a weaving mill, dyeing plant, bleaching plant, warehouses and other buildings. One of these is located in the place of the mill (Fig. 3 - 7). Cotton production lasted there for 150 years. For all that time, the old mill pond had an industrial function and prevented fires. Today, the area of the Grohmann Empire is renovated and since 1997 has been run as a Lodz Special Economic Zone (Photo 4). 


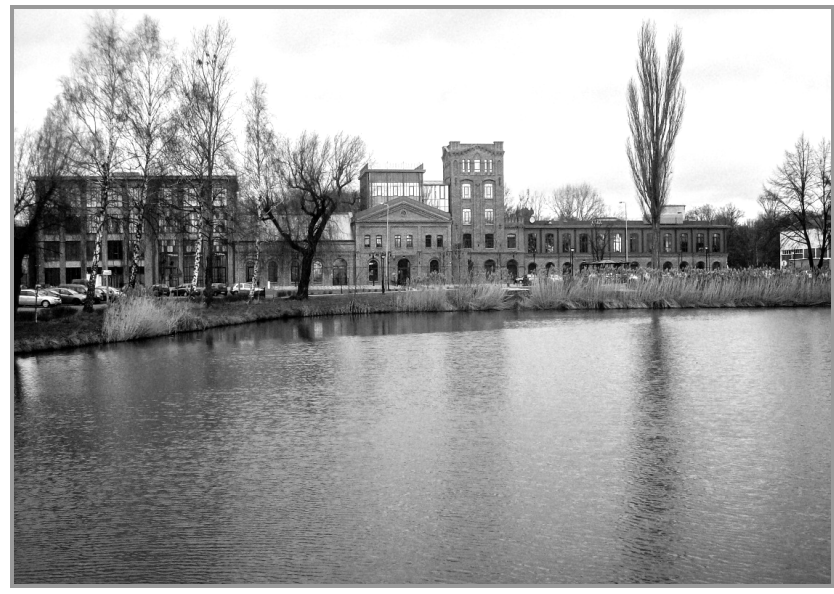

Photo 4. The headquarters of Lodz Special Economic Zone in the power plant of the Grohmann factory Photo: P. Moniewski

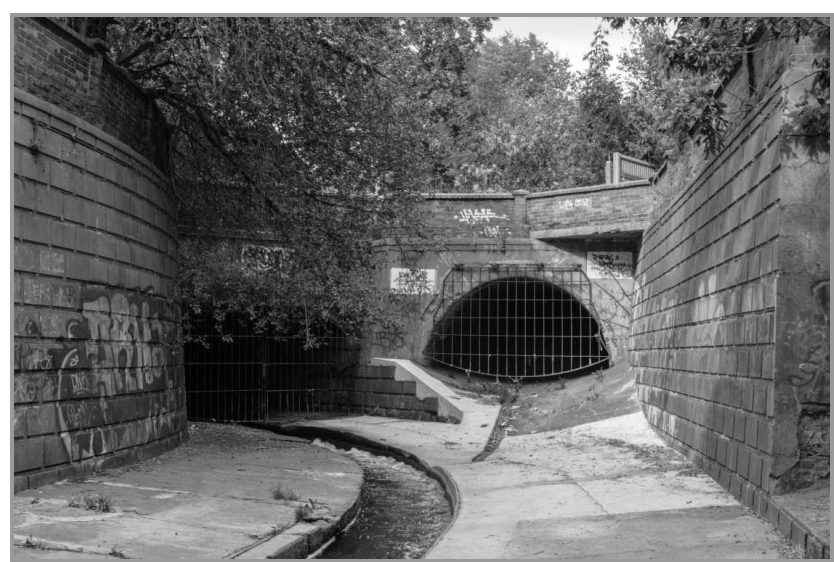

Photo 5. The Jasień and Dąbrówka (open temporary) near Wólczańska St

Photo: J. Jędruszkiewicz

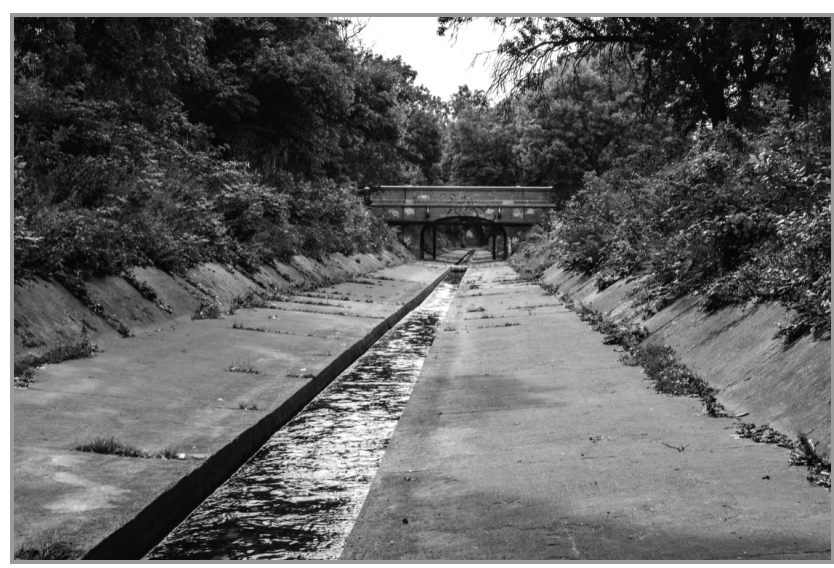

Photo 6. The concrete river channel of the Jasien: the brick bridge in the distance is next to Cieszkowskiego St Photo: J. Jedruszkiewicz

In 1897-8 the New Weaving Mill was constructed beneath Kilińskiego St directly above the Jasien for more effective sewage disposal. Today the subsurface course of the river leads along Milionowa St. Another new reservoir beside the Jasien, dammed by the Piotrkowska St dyke, was built in 1825-7 by J. Rundzieher. It was used as a power source for a linen spinning mill and wool dyeing plant (near Czerwona St). Originally it was twice as large as today. In the 1830 s and 40 s the area around the pond was gradually reclaimed by L. Geyer who constructed the White Factory on its north side and founded a park in the English style (Fig. 3 - 8). Nevertheless, due to significant river contamination today it is not connected to the pond. The pond in area 0.9 ha and depth $1.9 \mathrm{~m}$ is supplied by municipal water. In 2015 the pond and park were renovated.

Beneath Piotrkowska St, the stream is supplied by two tributaries. The right one, from the area of the University of Technology and on the left is the Dabrówk $a$. The culvert ends near Wólczańska St, where the river appears on the surface (Fig. 3 - 9 and Photo 5). In this part of its course, river engineering was undertaken in the 1930s (Photo 6).

Rokicie Mill operating for Rokicie village is another hydro-technical construction from the Middle Ages worth mentioning. The original building is dated to 1555-9. The wheel was powered by water from the reservoir. In the 1880s a steam mill was opened (Fig. 3 - 10). At the end of the $19^{\text {th }}$ c. Wenecja Park (today Słowackiego Park) with numerous ponds was founded by Reich. Currently the old mill building on Cieszyńska St 10 is closed (Photo 7).

The first significant tributary, the Karolewka, flows into the Jasień near Laskowicka St (Fig. 3 -11). Most of its course is in a hidden culvert, except the last $800 \mathrm{~m}$. There is distinct possibility that in the $19^{\text {th }} \mathrm{c}$. that Baczzek Mill was located by the Karolewka at the crossroads of Wróblewskiego and Bratysławska Sts (Fig. 3 12). It is believed that this mill might be known as Retkiński Mill (BARANOWSKI et al. 1980, p. 105). Below the Karolewka confluence with the Jasien is the only 'wild' unregulated section of the river. This part of the Jasien is deeper and includes numerous sand bars and bank slides (Photo 8). There was a plan to construct a dry flood-control reservoir 'Rokicie' with a size of 4.52 ha. Nevertheless, in the farther future, the Jasien riverbanks will be fortified with concrete.

In the lower course of the Jasien, the early mill settlement 'Chachuta' was established in the $16^{\text {th }} \mathrm{c}$. The mill was built on a dam of water storage along Zabrzeżna St (Fig. 3 - 13). In the second part of the $19^{\text {th }} \mathrm{c}$. environmental degradation resulted in fish deaths. In the $20^{\text {th }} \mathrm{c}$. the land of Chachuty was divided into parcels and inhabited, the pond was buried and the mill was demolished in the 1970s. The only evidence of the settlement are the street names (Chachuty and Chachulska Górka). 


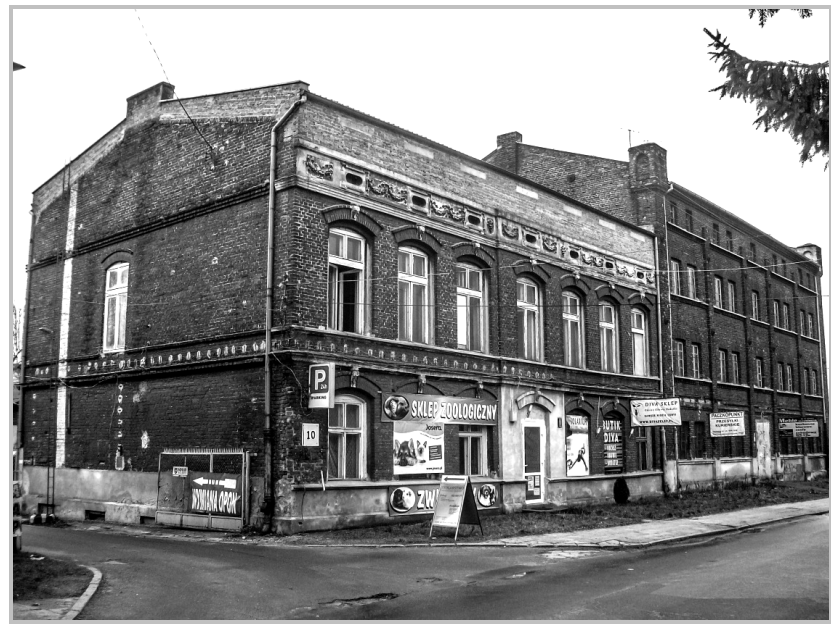

Photo 7. The old mill building 'Rokicie' on Cieszyńska St 10 Photo: P. Moniewski

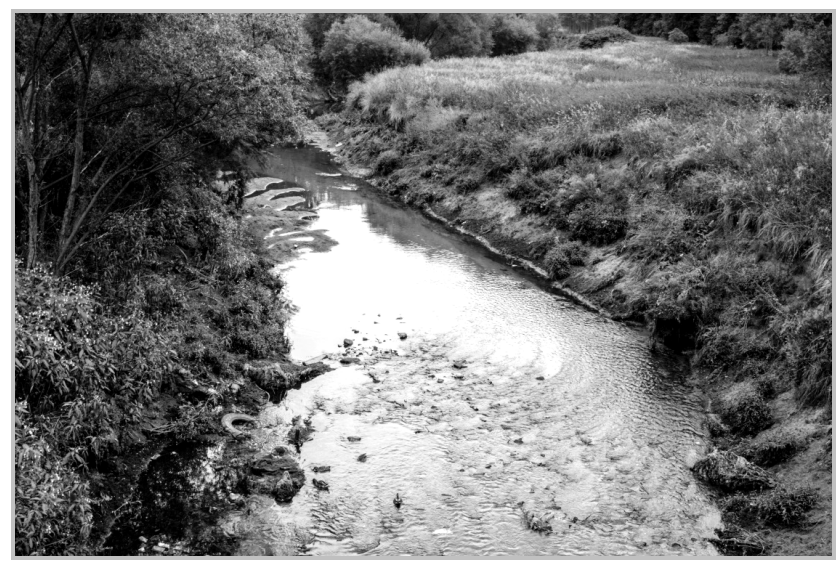

Photo 8. Unregulated section of the Jasień above Prądzyńskiego St Photo: J. Jędruszkiewicz

The major tributary of the Jasien is the Olechówka (Fig. 3 - 14). The catchment of the Olechówka has a different character than the Jasień. The original, agricultural character of villages located by the Olechówka (Olechów, Augustów or Chojny) has changed into residential. Because of its agricultural function, the Olechówka catchment area was poorly equipped with hydro-technical constructions. Despite its similar length of $12.3 \mathrm{~km}$, the gradient was only $3 \%$. On the other hand, the hilly area was covered with windmills which supplemented the work of watermills. The Olechówka has not performed any significant role in the industrial history of Łódź. The dry reservoir for firefighting near Olechowska St was built in 1981-6 (Fig. 3 -15). After reconstruction it is a system of two storage reservoirs 'Olechów Górny' and 'Olechów Dolny' (still under construction). In the 1970s a sedimentation tank was built next to Tomaszowska St and another near the pond 'Mtynek'. From the Middle Ages, Wiskitno Mill was associated with 'Mtynek' and was operated for Wiskitno village (Fig. 3 - 16). The last mill in that area was demolished during the interwar period. A small recreation centre is located on the pond shore (water sports equipment rental, beach).

On the eastern side of Rzgowska St, there is an extensive recreation centre, called 'Jan's Ponds'. That flow-through pond is the only one remaining of a system of ponds. In the past, there was a Chojeński Mill near the dam in Chojny village (Fig. 3 - 17). In 1672 , in addition to the mill, a small wooden manor house, warehouses and a brewery were erected. A third mill (Koc, Urban) was located half a mile from Chojeński Mill. The Olechówka catchment still has an agricultural function and low spates are captured by the flood protection reservoirs, 'Rzemieślnicza Dolny', constructed in 2008 (Fig. 3 - 18).

It is worth mentioning, that despite having no significant influence on industry the Olechówka is an integral part of the Jasień catchment. The low degree of environmental degradation makes that area attractive for recreation. Furthermore, Jan's Pond is known as a swimming area not possible for the Jasień as a result poor water quality. The open character of the Olechówka gives an opportunity to plan a new, attractive cycling and pedestrian paths, in contrast to the subsurface Jasień.

\section{SUMMARY}

Almost quarter of a century has passed since the company which drained toxic sewage into the Jasien was closed. According to measurements by the Regional Inspectorate of Environmental Protection in Łódź, sanitary conditions in the river are slightly but steadily improving. In recent years, a further improvement has been noticed as a result of water draining from the reconstruction of the Eódź Fabryczna railway station (BARTNIK \& MONIEWSKI 2015, p. 59-61). However the quality of the water is still poor. The sewage system, which was constructed in the 1920s, temporarily (during floods) is unable to stop sewage from getting into the river. It is bizarre that several hundred meters from the Olechówka, the turbid water flows from the Jasien into the much larger and cleaner water of the Ner, which had been highly polluted by Łódź industrial wastewater for decades. In the past the Olechówka was as wide as the Ner but currently is nothing but a narrow watercourse flowing along a concrete channel. Has it not deserved a better fate?

The complete revitalization of the Jasien is impossible. Even its partial reinstatement to Łódz's inhabitants is a great challenge for the following decades. Nevertheless, the protection of every part of this hydro-technical and industrial heritage is an 
urgent issue. A comparable example might be the revitalization investment of the Morris Canal (USA) which was covered over in the 1960s. River reconstruction requires water quality improvement and groundwater sourcing restoration first. To terminate the further contamination of the Jasien, new water and wastewater regulations are necessary. One of the approaches to restore the natural water cycle is to allow the rainwater to infiltrate through the ground (plots, 'absorbent' wells) instead of flowing directly into the river. The Jasien catchment should become a complex educational and recreational system, and should preserve historical heritage at the same time. That issue should be implemented in urban planning. The main idea is to create a historical and industrial park, which might become a trans-regional tourism attraction.

Taking a proper care for industrial heritage is the first step in the rational use of tourism potential in urban space (KRONENBERG 2009, p. 192). Suitable exposure of industrial constructions and shifts in its functions should be the main tasks considered in urban planning policy. An excellent example is the 'Green Ring of Tradition and Culture' (LISZEWSKI 2009, p. 64). The ring merges parts of the open spaces surrounding $19^{\text {th }} \mathrm{c}$. industrial Łódź (for example industrial buildings, sports facilities or other elements of the cultural heritage). That is an effective approach for an improvement of the tourism offer in Łódź.

\section{BIBLIOGRAPHY}

BARANOWSKI B., FIJAŁEK J., ROSIN R., 1980, Łódź: Dzieje miasta, t. 1: Do 1918 r., PWN, Warszawa, 674 pp.

BARTNIK A., MONIEWSKI P., 2015, Zmiany jakości wód łódzkiego Jasienia w wyniku głębokiego odwodnienia terenu w związku z budową dworca kolejowego Łódź Fabryczna, [in:] D. Absalon, M. Matysik, M. Ruman (eds.), Nowoczesne metody i rozwiazzania w hydrologii i gospodarce wodnej, Monografie Komisji Hydrologicznej PTG, Sosnowiec, pp. 59-73.

BIEŻANOWSKI W., 2003, Łódka $i$ inne rzeki tódzkie, Towarzystwo Opieki nad Zabytkami, Łódź, 96 pp.

CYMERMAN B., JERMACZEK-SITAK M., KRAKOWSKI J., ŚWIDEREK G., 2012, Z nurtem łódzkich rzek, Ośrodek Działań Ekologicznych „Źródła”, Łódź, 81 pp.

FlATT O., 1853, Opis miasta Łodzi pod względem historycznym, statystycznym i przemystowym, Warszawa, $150 \mathrm{pp}$.

GOŹDZIK J., WIECZORKOWSKA J., 2002, Rzeźba terenu, [in:] S. Liszewski (ed.), Atlas miasta Łodzi, Łódzkie Towarzystwo Naukowe, Łódź, $67 \mathrm{pp}$.

Ilustrowana encyklopedia historii Łodzi, 2009, Urząd Miasta Łodzi, Łódź, 342 pp.

JOKIEL P., MAKSYMIUK Z., 2002, Wody, [in:] S. Liszewski (ed.), Atlas miasta Łodzi, Łódzkie Towarzystwo Naukowe, Łódź, 67 pp.

KOTER M., 1974, Środowisko przyrodnicze obszaru obecnej Łodzi jako podłoże rozwoju osadnictwa $w$ okresie przedprzemysłowym, „Materiały i Studia”, 1, Rada Naukowa przy Prezydencie Miasta Łodzi, Łódź, 85 pp.

KOZŁOWSKA B., 2012, Rewitalizacja terenów nadrzecznych: REURIS - Stary Kanat Bydgoski, II Kongres Rewitalizacji Miast, Kraków, 12-14 września 2012 r., 30 pp.

KRONENBERG M., 2009, Rozwój miejskiej przestrzeni turystycznej opartej na dziedzictwie przemysłowym, Prace Geograficzne, 121, pp. 191-198.

MAURER A., 2013, Przywrócenie rzeki miastu w kontekście rewitalizacji miast poprzemysłowych - wybrane przykłady, Przestrzeń $i$ Forma, 19, pp. 151-162.

LISZEWSKI S., 2009, Miejska przestrzeń eksploracji turystycznej (przykład Łodzi), Turyzm, 19, 1-2, pp. 59-65.

LISZEWSKI S., 1995, Przestrzeń turystyczna, Turyzm, 5, 2, pp. 87-103.

Puś W., 1987, Dzieje Łodzi przemystowej (zarys historii), Muzeum Historii Miasta Łodzi, Łódź, 150 pp.

Rastrowa mapa podziału hydrograficznego Polski (MPHP) w skali 1 : 50 000, 2010, KZGW, http:/ / www.kzgw.gov.pl.

RYNKOWSKA A., 1960, Początki rozwoju kapitalistycznego miasta Łodzi, t. IV (1820-1864), Wyd. Książka i Wiedza, Warszawa, $555 \mathrm{pp}$.

Article received:

31 August 2015 